\title{
Preliminary study on otolith chemistry and otolith morphology of two demersal fish species, European hake (Merluccius merluccius Linnaeus, 1758) and striped red mullet (Mullus surmuletus Linnaeus, 1758) in the Sea of Marmara
}

\section{Marmara Denizi'nde iki demersal balık türünün bakalyaro (Merluccius merluccius Linnaeus, 1758) ve tekir (Mullus surmuletus Linnaeus, 1758)'in otolit kimyası ve otolit morfolojisi üzerine ön çalışma}

\author{
Habib Bal ${ }^{*}$ - Selim Esen ${ }^{2}$ \\ ${ }^{1}$ Republic of Turkey Ministry of Agriculture and Forestry, Erdek Directorate of District Agriculture and Forestry, \\ Department of Fisheries, Balıkesir, Turkey \\ ${ }^{2}$ Republic of Turkey Ministry of Agriculture and Forestry, Balıkesir Directorate of Provincial Agriculture and Forestry, (D) https://orcid.org/0000-0003-4953-7960 \\ Balıkesir, Turkey
}

\section{How to cite this paper:}

Bal, H. \& Esen, S. (2021). Preliminary study on otolith chemistry and otolith morphology of two demersal fish species, European hake Merluccius merluccius (Linnaeus, 1758) and striped red mullet (Mullus surmuletus, Linnaeus, 1758) in the Sea of Marmara. Ege Journal of Fisheries and Aquatic Sciences, 38(4), 515-521. DOI: 10.12714/egejfas.38.4.13

\begin{abstract}
Otoliths are calcium carbonate $\left(\mathrm{CaCO}_{3}\right)$ accumulations. Under the influence of different ecosystems morphological and chemical composition change. In this study, economically important two demersal fish species; European hake Merluccius merluccius (Linnaeus, 1758) and Stripet red mullet (Mullus surmuletus Linnaeus, 1758) was examined. Otoliths (Sagitta) belonging to these two species have been studied both chemically and morphologicall. Morphometric measurements of otoliths (length, $\mathrm{mm}$; width, $\mathrm{mm}$; area, $\mathrm{mm}^{2}$; perimeter, $\mathrm{mm}$ ) in the sagittal of each species was made by the Leica M125 triocular microscope. In the chemical analysis of otoliths, strontium $(\mathrm{Sr})$, magnesium $(\mathrm{Mg})$ and calcium $(\mathrm{Ca}$ ) trace element amounts, the ratios of $\mathrm{Sr}$ and $\mathrm{Mg}$ trace elements to $\mathrm{Ca}$ element $(\mathrm{Sr} / \mathrm{Ca}$ and $\mathrm{Mg} / \mathrm{Ca}$ ) were determined. For the micro-chemical analysis of otoliths ICP-MS was used. The highest magnesium $(24.92 \pm 9.57 \mathrm{mmol} / \mathrm{mol})$ and strontium $(26.17 \pm 1.81 \mathrm{mmol} / \mathrm{mol})$ element values were found in the otolith of red mullet. The difference between strontium (Sr) and magnesium $(\mathrm{Mg})$ amounts for two fish species was found to be significant $(P<0.05)$. In addition to it was found that the difference between them in the amount of calcium is significant $(P<0.001)$. The shape indexes of otoliths are significantly different between the two fish species. Especially in terms of roundness $\left(R_{D}\right)$ and aspect ratio $\left(A_{R}\right)(P<0.001)$. The results of this study provide information about the habitats of two economic importance demersal fish species. Since such studies can give information about the habitat areas of fish species, they are important for tracking stocks, migration routes and sustainable fisheries.

Keywords: Demersal fish, otolith chemistry, otolith morphology, Sea of Marmara

Öz: Otolitler kalsiyum karbonat $\left(\mathrm{CaCO}_{3}\right)$ birikimleridir. Farklı ekosistemlerin etkisi altında morfolojik ve kimyasal olarak değişmektedir. Bu çalışmada, ekonomik olarak önemli iki demersal balık türü; Bakalyaro Merluccius merluccius (Linnaeus, 1758) ve tekir (Mullus surmuletus Linnaeus, 1758) balığına ait otolitler (Sagitta) hem kimyasal hem de morfolojik olarak incelenmiştir. Otolitlerin (uzunluk, mm; genişlik, mm; alan, $\mathrm{mm}^{2}$; çevre, mm) morfometrik ölçümleri Leica M125 tri-oküler mikroskop ile yapılmıştı. Otolit yapısındaki stronsiyum (Sr), magnezyum (Mg) ve kalsiyum (Ca) iz element miktarları ile Sr ve Mg eser elementlerinin $\mathrm{Ca}$ elementine $(\mathrm{Sr} / \mathrm{Ca}$ ve $\mathrm{Mg} / \mathrm{Ca}$ ) oranları belirlenmiştir. Otolitlerin mikro kimyasal analizi için ICP-MS kullanılmış̧ı. En yüksek magnezyum $(24,92 \pm 9,57 \mathrm{mmol} / \mathrm{mol})$ ve stronsiyum $(26,17 \pm 1,81 \mathrm{mmol} / \mathrm{mol})$ element değerleri tekir otolitinde tespit edilmiştir. İki balık türü için stronsiyum (Sr) ve magnezyum (Mg) miktarları arasındaki fark önemli bulunmuştur $(\mathrm{P}<0,05)$. Ayrıca kalsiyum miktarı açısından aralarındaki farkın oldukça önemli olduğu tespit edilmiştir $(P<0,001)$. Otolitlerin şekil indeksleri iki balık türü arasında önemli ölçüde, özellikle yuvarlaklık $\left(R_{D}\right)$ ve en boy oranı $\left(A_{R}\right)$ açısından önemli olduğu tespit edilmiştir $(P<0,001)$. Bu çalışmanın sonuçları, ekonomik önemi olan iki demersal balık türünün habitatları hakkında bilgi verdiğinden; stokları, gö̧̧ yolları ve sürdürülebilir balıkçılığın takibi açısından önem arz etmektedir.

Anahtar kelimeler: Demersal balık, otolit kimyası, otolit morfolojisi, Marmara Denizi
\end{abstract}

\section{INTRODUCTION}

Otolith are stable structures in terms of metabolic activity and calcium carbonate $\left(\mathrm{CaCO}_{3}\right)$ deposits (Degens et al., 1969; Pannella, 1971; Campana, 1999). There are three pairs of otoliths in sagitta, lapillus and asteriscus in bony fishes. They undertake the task of providing balance and hearing
(Popper and Coombs, 1980; Campana, 1999; Campana and Thorrold, 2001).

Otolith has been the subject of studies in many areas such as fish biology, fish ecology, fish stock detection, diet assessment, as well as age and growth (Campana, 1999; 
Friedland and Reddin, 1994; Tracey et al. 2006; GonzalezSalas and Lenfant, 2007; Barrett, 1990; Martucci et al., 1993; Velando and Freire, 1999; Turan, 2006; Morat et al., 2014; Başusta and Khan, 2021).

Otolith constitute a source of information and data for the identifying ichthyological taxa with systematic and fleet genetic studies. Scientific studies and applications on otolith are not limited to ichthyology. It is also possible to access indepth information about historical processes by using them in fields such as paleontology, stratigraphy, archeology and zoogeography (Schwarzhans, 1999).

The best evidence of fish movement is observing and following their movements from one place to another. However, these data are difficult to obtain for multiple life stages (Gillanders, 2005). Although the potential importance of movement, relatively little is known about how many fish species vary within and between populations (Quinn, 1993; Gowan et al., 1994). Therefore, a robust and cost-effective method is needed to determine the habitat origins and movements of fish and to describe the stock structure of fish species. Otolith element composition has recently proven to be a robust natural tag for tracking population structure, species life history, habitat areas and migration routes (Campana and Neilson, 1985; Rieman et al., 1994; Campana et al., 1995; Thorrold et al., 1997; Wells et al., 2000; Thorrold et al., 2001). The structures of otolith undergo differentiation ontogenetically under the influence of different ecosystems. Their structure is three-dimensional, but not all dimensions grow equally and at the same rate. It also varies significantly among species in terms of size, shape and chemical content (Campana and Thorrold, 2001). One of the fastest growing areas of fisheries science is the use of these calcined structures (otolith) to answer ecological questions about fish movement and habitat areas. Otolith's two properties make it particularly suitable for keeping records of the environment in which the fish live (Gillanders, 2005). European hake and stripet red mullet are the most economically important demersal fish species in Turkey Seas (Yıldı and Karakulak, 2018). It mainly inhabits rocky bottoms and soft substrates and undergoes vertical movements between 5 and $100 \mathrm{~m}$ in depth (Froese and Pauly, 2008).

However, stocks are gradually decreasing due to overfishing, which have been decreasing recently. According to the Turkey Statistical Institute (2018-2019) 1.019 tons of $M$. merluccius, 2.914 tons M. surmuletus and 1269 tons M. merluccius, 2341 tons $M$. surmuletus were caught, respectively (TUIK, 2021).

In this study, the amount of trace elements and morphological structures of otoliths was examined and evaluated comparatively to monitor the stocks of two important demersal fish species.

\section{MATERIAL AND METHODS}

A total of $10 \mathrm{M}$. merluccius and $10 \mathrm{M}$. surmuletus were obtained from fishing vessels in the Sea of Marmara (west of "Kapıdağ Peninsula"). Otoliths were examined both morphologically and in microchemical analysis.

\section{Otolith chemistry}

Whole otoliths (right and left) were used for otolith chemistry. For each otolith to reach a constant weight, it has been subjected to drying in glass tubes for $2 \mathrm{~h}$ in an oven set at $120^{\circ} \mathrm{C}$. The otolith samples whose drying was completed were weighed with a sensitive scale sensitive to approximately $0.001 \mathrm{~g}$ and transferred to the vessels in the microwave incinerator unit. Then, $5 \mathrm{ml}$ of nitric acid $\left(\mathrm{HNO}_{3}\right)$ and $2 \mathrm{ml}$ of hydrogen peroxide $\left(\mathrm{H}_{2} \mathrm{O}_{2}\right)$ were added to each vessel and subjected to heat-controlled microwave combustion using the SK-12 rotor in the Easy model Ethos (Rooker et al., 2001; Correia et al., 2011). After the extract reached room temperature, the final volume was diluted with $25 \mathrm{ml}$ of distilled water and analyzed in solution mode on a Perkin Elmer brand Nexion 350X model Inductively Coupled Plasma Mass Spectrometer ICP-MS (Jarvis and Jarvis, 1992).

At the end of the analysis, strontium (Sr), calcium (Ca) and magnesium $(\mathrm{Mg})$ trace element concentrations and elemental calcium ratios $(\mathrm{Sr} / \mathrm{Ca}$ and $\mathrm{Mg} / \mathrm{Ca}$ ) were determined.

\section{Otolith morphology}

Firstly, the length (with a height measuring scale with 0.01 $\mathrm{mm}$ precision) and weight measurements (in $0.01 \mathrm{~g}$ precision balance) of the fish samples were examined. The sagitta otoliths were removed and soaked in 3\% hydrogen peroxide $\left(\mathrm{H}_{2} \mathrm{O}_{2}\right)$ and $1 \%$ nitric acid $\left(\mathrm{HNO}_{3}\right)$ for 5 min, respectively, to purify the blood, tissue and other surface contaminants. It was then kept in distilled water for 5 min to remove the acid (Rooker et al., 2001). There were no differences between right and left otolith of both species ( $t$-test, $P>0.05$ ). Therefore, the right otolith was used for the measuring the otolith morphology of two fish species. Otolith length (OL) and otolith width $(\mathrm{OW})( \pm 0.001 \mathrm{~mm})$ were determined by Leica M125. Otolith length was defined as the greatest distance between the anterior and posterior edge and otolith width was described as the greatest distance from dorsal to the ventral edge. To illustrate how measurements of otolith morphology are made $M$. merluccius otolith measurements are given as an example (Figure 1).

The raw data obtained at the end of the measurement [otolith length $(\mathrm{OL}, \mathrm{mm})$, otolith width $(\mathrm{OW}, \mathrm{mm})$, otolith area $\left(\mathrm{OA}, \mathrm{mm}^{2}\right)$ and otolith perimeter (OP, $\left.\left.\mathrm{mm}\right)\right]$ was evaluated and the shape indexes of was calculated. The otolith shape identification process helps construct the otolith atlas and identify the species (Tuset et al., 2008). The formulas given in Table 1 were used to determine the shape indexes of otoliths (Tuset et al., 2003; Ponton, 2006). 


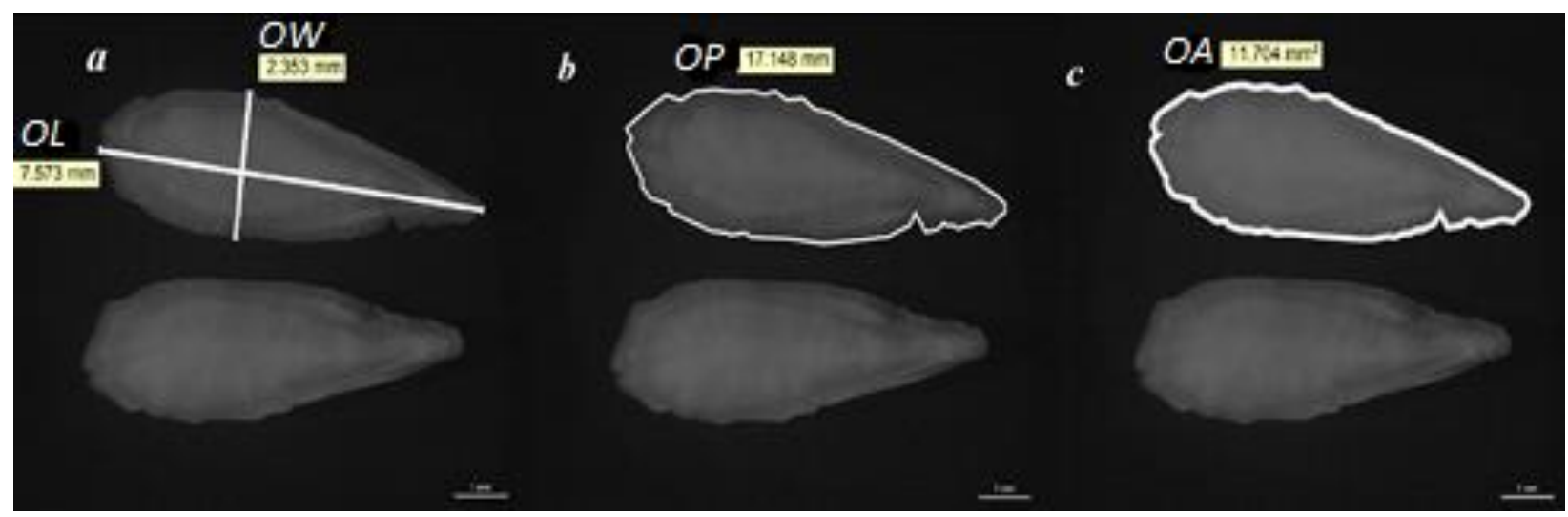

Figure 1. a: OL otolith length $(\mathrm{mm})$; OW: otolith width $(\mathrm{mm})$; b: OP otolith perimeter $(\mathrm{mm}) ; \mathrm{c}$ : OA otolith area $\left(\mathrm{mm}^{2}\right)$; measurement: $1 \mathrm{~mm}$. Photos by H. BAL)

Table 1. Formulas to be used for the shape index otoliths of the species

\begin{tabular}{lll}
\hline Parameters & Shape indexes & Formula \\
\hline OP (otolith perimeter, mm) & Form Factor $\left(\mathrm{F}_{\mathrm{F}}\right)$ & $4 . \pi \cdot \mathrm{OA} /(\mathrm{OP})^{2}$ \\
$\mathrm{OA}$ (otolith area, $\left.\mathrm{mm}^{2}\right)$ & Circularity $\left(\mathrm{C}_{\mathrm{i}}\right)$ & $(\mathrm{OP})^{2} / \mathrm{OA}$ \\
$\mathrm{OL}$ (otolith length, $\mathrm{mm})$ & Roundness $\left(\mathrm{R}_{\mathrm{D}}\right)$ & $4 . \mathrm{OA} / \pi \cdot(\mathrm{OL})^{2}$ \\
$\mathrm{OW}_{\mathrm{i}}$ (otolith witdh, $\left.\mathrm{mm}\right)$ & Width/Length $(\mathrm{W} / \mathrm{L})$ & $\mathrm{OL} . \mathrm{OW}^{-1}$
\end{tabular}

The results of this study provide information about the habitats of two demersal fish species that have economic importance and share the same habitat. Since such studies can give information about the habitat areas of fish species, they are important for tracking stocks, migration routes and sustainable fisheries.

\section{Statistical analysis}

One-way analysis of variance (ANOVA) was performed using the SAS package program (Version: 6.0.0) to determine the differences between two demersal fish species on otolith chemistry and morphology.

\section{RESULTS}

Both chemical and morphological analysis was performed on otolith belonging to two demersal fish species.

\section{Otolith chemistry}

Chemical trace elements ( $\mathrm{Sr}, \mathrm{Mg}$ and $\mathrm{Ca}$ ) in otoliths belonging to two demersal fish species were investigated. It was determined that the highest value among the three trace elements was in otoliths belonging to $M$. surmuletus species and the average amount of strontium as $26.17 \pm 1.81$ $\mathrm{mmol} / \mathrm{mol}$ was determined. Similarly, it was determined that the highest amount of $\mathrm{Mg}$ was in M. surmuletus (24.92 \pm 9.57 $\mathrm{mmol} / \mathrm{mol}$ ). However, calcium trace element (Ca) content of M. merluccius was found to be $10.2 \pm 0.07 \mathrm{mmol} / \mathrm{mol}$ higher than $M$. surmuletus. The difference between strontium (Sr) and magnesium (Mg) amounts for the two fish species was found to be significant $(P<0.05)$. It was found that the difference between them in the amount of calcium is significant $(P<0.001)$. Data of fish size and otolith chemistry for two demersal species are given in Table 2.

Table 2. Data on otolith chemistry of two demersal fish species

\begin{tabular}{|c|c|c|c|c|c|c|c|}
\hline Species & $\begin{array}{c}\text { TL }(\mathrm{cm}) \\
\text { Min-max } \\
\text { Mean士SE }\end{array}$ & $\begin{array}{c}\text { W }(g) \\
\text { Min-max } \\
\text { Mean } \pm S E\end{array}$ & $\begin{array}{c}\mathrm{Sr} \\
(\mu \mathrm{mol} / \mathrm{mg}) \\
\text { Min-max } \\
\text { Mean } \pm S E\end{array}$ & $\begin{array}{c}\mathrm{Mg} \\
(\mu \mathrm{mol} / \mathrm{mg}) \\
\text { Min-max } \\
\text { Mean } \pm S E\end{array}$ & $\begin{array}{c}\mathrm{Ca} \\
(\mu \mathrm{mol} / \mathrm{mg}) \\
\text { Min-max } \\
\text { Mean } \pm S E\end{array}$ & $\begin{array}{c}\mathrm{Sr} / \mathrm{Ca} \\
(\mathrm{mmol} / \mathrm{mol}) \\
\text { Min-max } \\
\text { Mean } \pm \mathrm{SE}\end{array}$ & $\begin{array}{c}\mathrm{Mg} / \mathrm{Ca} \\
(\mathrm{mmol} / \mathrm{mol}) \\
\text { Min-max } \\
\text { Mean } \pm \text { SE }\end{array}$ \\
\hline $\begin{array}{l}\text { Merluccius } \\
\text { merluccius }\end{array}$ & $\begin{array}{l}27.10-36.50 \\
31.54 \pm 0.98\end{array}$ & $\begin{array}{l}141.87-413.14 \\
264.97 \pm 28.53\end{array}$ & $\begin{array}{c}3.97-30.28 \\
15.51 \pm 2.99\end{array}$ & $\begin{array}{l}0.60-1.98 \\
1.26 \pm 0.18\end{array}$ & $\begin{array}{c}9.97-10.67 \\
10.25 \pm 0.07\end{array}$ & $\begin{array}{l}0.38-2.96 \\
1.52 \pm 2.11\end{array}$ & $\begin{array}{l}0.05-0.19 \\
0.12 \pm 0.11\end{array}$ \\
\hline $\begin{array}{l}\text { Mullus } \\
\text { surmuletus }\end{array}$ & $\begin{array}{r}13.50-18.0 \\
15.35 \pm 0.38\end{array}$ & $\begin{array}{l}25.75-75.83 \\
43.01 \pm 4.27\end{array}$ & $\begin{array}{l}20.46-38.30 \\
26.17 \pm 1.81\end{array}$ & $\begin{array}{l}5.63-105.96 \\
24.92 \pm 9.57\end{array}$ & $\begin{array}{l}7.49-10.50 \\
9.30 \pm 0.29\end{array}$ & $\begin{array}{l}2.42-3.64 \\
2.79 \pm 0.45\end{array}$ & $\begin{array}{l}0.57-14.17 \\
2.94 \pm 1.20\end{array}$ \\
\hline Sig. & $* * *$ & $\star \star * *$ & ** & *** & $* * *$ & ** & $* * *$ \\
\hline
\end{tabular}

TL: Total fish length (cm), W: Total fish weight (g); Sr: Strontium (mmol/mol); Mg: Magnesium (mmol/mol); Ca: Calcium (mmol/mol); SE: Standard error; Sig.: Significance, ${ }^{* *}: P<0.01,{ }^{* * *}: P<0.001$.

\section{Otolith morphology}

It was determined that the shape indexes obtained from the morphological analysis of the otoliths belonging to both fish species differ from each other. The otolith morphology of the two species was determined to be significantly different from each other. The minimum, maximum, mean and standard error of fish size and otolith measurement are given in Table 3. The raw data obtained at the end of the measurement [otolith length $(\mathrm{OL}, \mathrm{mm})$, 
otolith width $(\mathrm{OWi}, \mathrm{mm})$, otolith area $\left(\mathrm{OA}, \mathrm{mm}^{2}\right)$ and otolith perimeter $(\mathrm{OP}, \mathrm{mm})]$ was evaluated and the shape indexes of was calculated. The shape indexes differ significantly from each other. Especially in terms of roundness $\left(\mathrm{R}_{\mathrm{D}}\right)$ and aspect ratio $\left(\mathrm{A}_{R}\right)$ $(P<0.001)$. Data of morphological and shape indexes are given in Table 4.

Table 3. Descriptive statistics on fish size and otolith measurements

\begin{tabular}{|c|c|c|c|c|c|}
\hline \multirow{3}{*}{$\begin{array}{l}\text { Fish size and otolith } \\
\text { measurements }\end{array}$} & \multicolumn{5}{|c|}{ Species } \\
\hline & \multicolumn{2}{|c|}{ Merluccius merluccius } & \multicolumn{2}{|c|}{ Mullus surmuletus } & \multirow[b]{2}{*}{ Sig. } \\
\hline & Min-max & Mean \pm SE & Min-max & Mean $\pm S E$ & \\
\hline$\overline{\mathrm{TL}}(\mathrm{cm})$ & $27.10-36.50$ & $31.54 \pm 0.98$ & $13.50-18.0$ & $15.35 \pm 0.38$ & 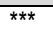 \\
\hline$W(g)$ & $141.87-413.1$ & $248.51 \pm 2.05$ & $25.75-75.83$ & $43.01 \pm 4.27$ & $\star * \star$ \\
\hline OW (mg) & $75.0-159.0$ & $107.70 \pm 7.81$ & $4.20-10.80$ & $6.08 \pm 0.64$ & $\star * \star$ \\
\hline $\mathrm{OL}(\mathrm{mm})$ & $10.09-13.33$ & $11.45 \pm 0.37$ & $2.11-3.01$ & $2.31 \pm 0.09$ & $* * *$ \\
\hline $\mathrm{OW}_{\mathrm{i}}(\mathrm{mm})$ & $3.96-5.82$ & $4.65 \pm 0.17$ & $1.41-1.99$ & $1.60 \pm 0.06$ & $\star * *$ \\
\hline $\mathrm{OA}\left(\mathrm{mm}^{2}\right)$ & $28.57-52.20$ & $37.13 \pm 2.24$ & $2.05-4.08$ & $2.48 \pm 0.19$ & $\star * *$ \\
\hline $\mathrm{OP}(\mathrm{mm})$ & $22.73-30.82$ & $25.98 \pm 0.83$ & $5.28-8.34$ & $6.32 \pm 0.31$ & $\star * *$ \\
\hline
\end{tabular}

TL: Total fish length $(\mathrm{cm})$, W: Total fish weight $(\mathrm{g})$, OW: Otolith weight $(\mathrm{mg})$, OL: Otolith length $(\mathrm{mm})$, OW: Otolith width $(\mathrm{mm})$, OA: Otolith area $\left(\mathrm{mm}^{2}\right)$, OP: Otolith perimeter (mm), SE: Standard error; Sig.: Significance, ${ }^{* \star *}: \mathrm{P}<0.001$.

Table 4. Fish size and otolith shape analysis

\begin{tabular}{|c|c|c|c|c|c|c|}
\hline Species & $\begin{array}{l}\text { TL }(\mathrm{cm}) \\
\text { Min-max } \\
\text { Mean } \pm S E\end{array}$ & $\begin{array}{l}\text { W }(g) \\
\text { Min-max } \\
\text { Mean } \pm S E\end{array}$ & $\begin{array}{l}\text { Circularity }\left(\mathrm{C}_{\mathrm{i}}\right) \\
\text { Min-max } \\
\text { Mean } \pm \mathrm{SE}\end{array}$ & $\begin{array}{l}\text { Form factor }\left(F_{F}\right) \\
\text { Min-max } \\
\text { Mean } \pm S E\end{array}$ & $\begin{array}{l}\text { Roundness }\left(R_{D}\right) \\
\text { Min-max } \\
\text { Mean } \pm S E\end{array}$ & $\begin{array}{l}\text { Aspect ratio }\left(A_{R}\right) \\
\text { Min-max } \\
\text { Mean } \pm S E\end{array}$ \\
\hline Merluccius merluccius & $\begin{array}{l}27.10-36.50 \\
31.54 \pm 0.98\end{array}$ & $\begin{array}{l}141.87413 .14 \\
248.51 \pm 2.05\end{array}$ & $\begin{array}{l}17.33-1977 \\
18.30 \pm 0.22\end{array}$ & $\begin{array}{l}0.635-0.725 \\
0.680 \pm 0.008\end{array}$ & $\begin{array}{l}0.325-0.378 \\
0.358 \pm 0.006\end{array}$ & $\begin{array}{l}2.292-2.600 \\
2.464 \pm 0.029\end{array}$ \\
\hline Mullus surmuletus & $\begin{array}{l}13.50-18.0 \\
15.35 \pm 0.38\end{array}$ & $\begin{array}{l}25.75-75.83 \\
43.01 \pm 4.27\end{array}$ & $\begin{array}{l}12.87-20.05 \\
16.33 \pm 0.83\end{array}$ & $\begin{array}{l}0.626-0.976 \\
0.789 \pm 0.042\end{array}$ & $\begin{array}{l}0.547-0.642 \\
0.592 \pm 0.009\end{array}$ & $\begin{array}{l}1.322-1.620 \\
1.445 \pm 0.030\end{array}$ \\
\hline Sig. & $* * *$ & $* * *$ & * & * & *** & $* * *$ \\
\hline
\end{tabular}

TL: Total fish length (cm); W: Total fish weight (g); OW: Otolith weight (mg); SE: Standard error; Sig.: Significance; ${ }^{*} \mathrm{P}<0.05 ;{ }^{* * *}$ : $\mathrm{P}<0.001$.

\section{DISCUSSION}

Although the potential importance of the movement, relatively little is known about the populations of many fish species (Quinn, 1993; Gowan et al., 1994). Therefore, there is a need for a robust and cost-effective method to determine the habitat origins and movements of fish and to describe the stock structure of fish species. Otolith element composition has recently proven to be a powerful natural label for tracking population structure, species life histories, habitat ranges, and migration routes (Campana and Neilson, 1985; Rieman et al., 1994; Campana et al., 1995; Thorrold et al., 1997; Wells et al., 2000; Thorrold et al., 2001).

Although M. merluccius and M. surmuletus are demersal fish species, it has been determined that the chemical element amounts and ratios of otoliths belonging to $M$. surmuletus were higher than M. merluccius. Especially, when compared to the otolith size of $M$. surmuletus, $\mathrm{Sr} / \mathrm{Ca}$ and $\mathrm{Mg} / \mathrm{Ca}$ ratios are observed to be higher although it is much smaller than $M$. merluccius. Similarly, although $M$. surmuletus otolith is lighter (Mean $\pm S E ; 6.08 \pm 0.64 \mathrm{mg}$ ) than $M$. merluccius otolith (Mean $\pm S E ; 107.70 \pm 7.81 \mathrm{mg}$ ), it contains higher amounts of $\mathrm{Sr}$ and $\mathrm{Mg}$ trace elements (Table 2 and Table 3). But, calcium ( $\mathrm{Ca}$ ) trace element content of $M$. merluccius was found to be $10.2 \pm 0.07 \mathrm{mmol} / \mathrm{mol}$ higher than
M. surmuletus. According to the results of scientific studies, it has been determined that salinity, temperature and conditional environmental effect the otolith chemistry (Secor et al., 1995; Hoff and Fuiman, 1995; Elsdon and Gillanders, 2004). It is thought that the differences between species in the inclusion of elements in our study may be partially related to environmental conditions, differences in metabolic and otolith deposition rate (Hamer and Jenkins, 2007).

This study is the first to examine the otolith chemistry and morphology of these two demersal species for Turkish waters and there is no study using this method for M. merluccius and $M$. surmuletus fish species in Turkey Seas. Therefore, no comparison could be made.

Only one study has been detected as research that examines both the morphological and analysis of the chemical structure of otoliths in Turkey Seas. Within the scope of the research, the horse mackerel (Trachurus mediterraneus Steindachner, 1868) was examined and a significant contribution was made to the separation of the stocks related to the species (Turan, 2006). Apart from this study, otolith $\mathrm{Sr} / \mathrm{Ca}$ ratios were examined to determine the migration characteristics of the European eel (Anguilla anguilla Linnaeus, 1758) species in the Asi River (Lin et al., 2011). The average ratio of $\mathrm{Sr} / \mathrm{Ca}$ in otoliths of $A$. anguilla 

red mullet (Mullus surmuletus, Linnaeus, 1758) in the Sea of Marmara

taken from the Asi River was determined as $2.79 \times 10^{-3} \mu \mathrm{m}$, which is approximately twice time $\left(1.4 \times 10^{-3} \mu \mathrm{m}\right)$ the ratio of $\mathrm{Sr} / \mathrm{Ca}$ in otliths of samples taken from the Garonne and Dordogne rivers (Lin et al., 2011). Thus, it was determined that the same fish species exist in different habitats by using otolith chemistry.

However, there are many studies examining otolith chemistry and morphology of two demersal fish species in different seas of the world (Torres et al., 2000; Lombarte et al., 2003; Morales-Nin et al., 2005; Swan et al., 2006; Leakey et al., 2009; Mahe et al., 2014; Morales-Nin et al., 2014; Bakkari et al., 2020).

In different study, it has been determined that $\mathrm{Mg}$ and $\mathrm{Sr}$ amounts in otoliths of fish samples (M. merluccius) taken from five different geographical locations (in north-east Atlantic and the Western Mediterranean Sea) is significantly different between the sample locations (Morales-Nin et al., 2005).

In another study on otolith chemistry was used to determine the relationship among populations of European hake; it was found that the ratio of Sr:Ca in the otolith core was higher than the otolith edge of the European hake. Also, the otolith edge had lower ratios for all elements except $\mathrm{Mg}$ (Morales-Nin et al., 2014). This situation shows that the habitat areas in which the juvenile stages, which are the first life stages of the fish, may differ from the adult stages. Another idiom on the otolith morphology of European hake was investigated for two different areas (North-eastern Atlantic-Cantabrian Sea and the Mediterranean Sea-Gulf of Lion). In the study, fish lengths are between 14 and $77 \mathrm{~cm}$ and $21-70 \mathrm{~cm}$, and the average otolith area, otolith perimeter and otolith length of the samples in the North Atlantic were calculated as $80.15 \mathrm{~mm}^{2}, 102.01 \mathrm{~mm}$, and $17.71 \mathrm{~mm}$, respectively. In the Mediterranean, the average otolith area, otolith perimeter and otolith length were calculated as 102.78 $\mathrm{mm}^{2}, 118.8 \mathrm{~mm}$, and $19.6 \mathrm{~mm}$, respectively (Torres et al., 2000). Another idiom conducted in the Mediterranean, trace elements of the European otoliths were examined.

All otoliths from M. merluccius separate areas differed not only in elemental concentrations but also in the distribution of elements among different individuals. For example, significant differences were found in the otolith concentrations between $\mathrm{Mg}, \mathrm{Mn}$ and $\mathrm{Sr}$ among individuals in the Mediterranean region (Swan et al., 2006).

Although many factors such as the amount of accumulation of chemical trace elements, fish physiology, stress and genetics are effective, it may vary in proportion to environmental conditions, especially temperature and salinity (Reis Santos et al., 2013; Avigliano et al., 2014; Sarimin and Mohamed, 2014). The amount of strontium element increases positively depending on the salinity of the water (Kraus and Secor, 2004; Sturrock et al., 2012; Avigliano and Volpedo, 2013). However, barium is negatively affected (Miller, 2011;
Avigliano et al., 2014). Calcium (Ca) is physiologically included in otoliths (Popper et al., 2005). However, magnesium increases depending on the metabolic activity and growth in the ecosystem where the fish is located (Martin and Thorrold, 2005; Sturrock et al., 2015; Grammer et al., 2017). Also, strontium (Sr) and magnesium (Mg) are included in the otolith chemistry according to the natural abundance of trace elements carried by the fish habitat and chemical property of water (Farrell and Campana, 1996).

Additionally, environmental conditions affect the morphology of otoliths may differ between populations of the same species (Congiu et al., 2002). Determination of shape indices such as circularity and roundness by using the structural shapes and sizes of otoliths that change in a morphological sense and identification of species are secondary areas of use that help to determine the differences between stocks of the same species depending on geographical distance (Ponton, 2006; Campana and Casselman, 1993; Torres et al., 2000; Monteiro et al., 2005). In this study, the otolith morphology of two demersal fish species was investigated. Although samples from different regions cannot be taken and analyzed, in the present study findings are expected to form complementary data that will be a source for future scientific research on similar species. There are many studies examining the morphology of otoliths for descripting fish stocks in different parts of the world and in Seas of Turkey (Campana and Casselman, 1993; Campana et al., 1995; Monteiro et al., 2005; Özpiçak et al., 2017; Bal et al., 2018). They made a significant contribution to the stock descriptions of the investigated species in these studies.

Since the same trace elements and the same morphological features were not examined in other studies, a comprehensive comparison could not be made with the present study.

\section{CONCLUSION}

The differences between the stocks of demersal species and their habitat areas are not yet well known. It is of great importance to define the habitats of these important fish species, which can be considered the basic stone of the marine ecosystem, the characteristics of their habitat areas and the stocks. Because; if the stocks and habitat areas of the species are not analyzed well, it is obvious that the extinction of the species will be endangered as these areas cannot be protected since stocks cannot be distinguished and defined.

However, samples could not be taken from different regions due to some limiting factors such as the costs required for laboratory analysis. To determine the differences between stocks in more detail, complementary studies are needed. It is thought that the findings obtained from this study will be a source for future research. 


\section{REFERENCES}

Avigliano, E., Martinez, C.F.R. \& Volpedo, A.V. (2014). Combined use of otolith microchemistry and morphometry as indicators of the habitat of the silverside (Odontesthes bonariensis) in a freshwater-estuarine environment. Fisheries Research, 149, 55-60.

DOI: 10.1016/j.fishres.2013.09.013

Avigliano, E. \& Volpedo, A.V. (2013). Use of otolith strontium: calcium ratio as an indicator of seasonal displacements of the silverside (Odontesthes bonariensis) in a freshwater-marine environment. Marine and Freshwater Research, 64(8), 746-751. DOI: 10.1071/MF12165

Bakkari, W., Mejri, M., Ben Mohamed, S., Chalh, A., Quignard, J.P. \& Trabelsi, M. (2020). Shape and Symmetry in the otolith of two different species Mullus barbatus and Mullus surmuletus (actinopterygii: perciformes: mullidae) in Tunisian waters. Acta Ichthyologica et Piscatoria, 50(2). DOI: 10.3750/AIEP/02760

Bal, H., Türker, D. \& Zengin, K. (2018). Morphological characteristics of otolith for four fish species in the Edremit Gulf, Aegean Sea, Turkey. Iranian Journal of Ichthyol, 5(4): 303-311

Barret, R. T. (1990). Diets of shags, Phalacrocorax aristotelis, and cormorants, $P$. carbo in Norway and possible implications for gadoid stock recruitment. Marine Ecology Progress Series, 66, 205-218. DOI: 10.3354/meps066205

Başusta, N. \& Khan, U. (2021). Sexual dimorphism in the otolith shape of shi drum, Umbrina cirrosa (L.), in the eastern Mediterranean Sea: Fish sizeotolith size relationships. Journal of Fish Biology. 99(1), 164-174. DOI: $10.1111 / \mathrm{jfb} .14708$

Campana, S.E. \& Neilson, J.D. (1985). Microstructure of fish otoliths. Canadian Journal of Fisheries and Aquatic Sciences, 42(5), 1014-1032. DOI: $10.1139 / f 85-127$

Campana, S.E. \& Casselman, J.M. (1993). Stock discrimination using otolith shape analysis. Canadian Journal of Fisheries and Aquatic Sciences, 50(5), 1062-1083. DOI: 10.1139/f93-123

Campana, S. E., Gagné, J. A. \& McLaren, J. W. (1995). Elemental fingerprinting of fish otoliths using ID-ICPMS. Marine Ecology Progress Series, 122, 115-120. DOI: 10.3354/meps122115

Campana, S.E. (1999). Chemistry and composition of fish otoliths: pathways, mechanisms and applications. Marine Ecology Progress Series, 188, 263-297. DOI: 10.3354/meps188263

Campana, S.E. \& Thorrold, S.R. (2001). Otoliths, increments, and elements: keys to a comprehensive understanding of fish populations?. Canadian Journal of Fisheries and Aquatic Sciences, 58(1), 30-38. DOI: 10.1139/f00-177

Congiu, L., Rossi, R. \& Colombo, G. (2002). Population analysis of the sand smelt Atherina boyeri (Teleostei Atherinidae), from Italian coastal lagoons by random amplified polymorphic DNA. Marine Ecology Progress Series, 229, 279-289. DOI: 10.3354/meps229279

Correia, A.T., Pipa, T., Gonçalves, J.M.S., Erzini, K. \& Hamer, P.A. (2011). Insights into population structure of Diplodus vulgaris along the SW Portuguese coast from otolith elemental signatures. Fisheries Research, 111(1-2), 82-91. DOI: 10.1016/j.fishres.2011.06.014

Degens, E.T., Deuser, W.G. \& Haedrich, R.L. (1969). Molecular structure and composition of fish otoliths. Marine Biology, 2(2), 105-113. DOI: 10.1007/BF00347005

Elsdon, T.S. \& Gillanders, B.M. (2004). Interactive effects of temperature and salinity on otolith chemistry: challenges for determining environmental histories of fish. Canadian Journal of Fisheries and Aquatic Sciences, 59(11), 1796-1808. DOI: 10.1139/f02-154

Farrell, J. \& Campana, S.E. (1996). Regulation of calcium and strontium deposition on the otoliths of juvenile tilapia, Oreochromis niloticus. Comparative Biochemistry and Physiology Part A: Physiology, 115(2), 103-109. DOI: 10.1016/0300-9629(96)00015-1
Friedland, K.D. \& Reddin, D.G. (1994). Use of otolith morphology in stock discriminations of Atlantic salmon (Salmo salar). Canadian Journal of Fisheries and Aquatic Sciences, 51(1), 91-98. DOI: 10.1139/f94-011

Froese, R. \& Pauly, D. (2008). World wideweb electronic publication. Retrieved on January 11, 2021 from www.fishbase.org.

Gillanders, B.M. (2005). Otolith chemistry to determine movements of diadromous and freshwater fish. Aquatic Living Resources, 18(3), 291300. DOI: 10.1051/alr:2005033

Gonzalez-Salas, C. \& Lenfant, P. (2007). Interannual variability and intraannual stability of the otolith shape in European anchovy Engraulis encrasicolus (L.) in the Bay of Biscay. Journal of Fish Biology, 70(1), 3549. DOI:10.1111/j.1095-8649.2006.01243.x

Gowan, C., Young, M.K., Fausch, K.D. \& Riley, S.C. (1994). Restricted movement in resident stream salmonids: a paradigm lost? Canadian Journal of Fisheries and Aquatic Sciences, 51(11), 2626-2637. DOI: 10.1139/f94-262

Grammer, G.L., Morrongiello, J.R., Izzo, C., Hawthorne, P.J., Middleton, J.F. \& Gillanders, B.M. (2017). Coupling biogeochemical tracers with fish growth reveals physiological and environmental controls on otolith chemistry. Ecological Monographs, 87(3), 487-507. DOI: $10.1002 / \mathrm{ecm} .1264$

Hamer, P. A. \& Jenkins, G.P. (2007). Comparison of spatial variation in otolith chemistry of two fish species and relationships with water chemistry and otolith growth. Journal of Fish Biology, 71(4), 1035-1055. DOI: 10.1111/j.1095-8649.2007.01570.x

Hoff, G.R. \& Fuiman, L.A. (1995). Environmentally induced variation in elemental composition of red drum (Sciaenops ocellatus) otoliths. Bulletin of Marine Science, 56(2), 578-591.

Jarvis, I. \& Jarvis, K.E. (1992). Plasma spectrometry in the earth sciences: techniques, applications and future trends. Chemical Geology, 95(1-2), 1-33. DOI: $10.1016 / 0009-2541(92) 90041-3$

Kraus, R. T. \& Secor, D. H. (2004). Incorporation of strontium into otoliths of an estuarine fish. Journal of Experimental Marine Biology and Ecology, 302(1), 85-106. DOI: 10.1016/j.jembe.2003.10.004

Leakey, C.D., Attrill, M J. \& Fitzsimons, M.F. (2009). Multi-element otolith chemistry of juvenile sole (Solea solea), whiting (Merlangius merlangus) and European seabass (Dicentrarchus labrax) in the Thames Estuary and adjacent coastal regions. Journal of Sea Research, 61(4), 268-274. DOI: 10.1016/j.seares.2008.12.002

Lin, Y.J., Yalçin-Özdilek, S., lizuka, Y., Gümüş, A. \& Tzeng, W.N. (2011). Migratory life history of European eel Anguilla anguilla from freshwater regions of the River Asi, southern Turkey and their high otolith $\mathrm{Sr}: \mathrm{Ca}$ ratios. Journal of Fish Biology, 78(3), 860-868. DOI: 10.1111/j.1095-8649.2011.02903.x

Lombarte, A., Torres, G.J. \& Morales-Nin, B. (2003). Specific Merluccius otolith growth patterns related to phylogenetics and environmental factors. Journal Marine Biology, 83: 277-281. DOI: $10.1017 / \mathrm{S} 0025315403007070 \mathrm{~h}$

Mahe, K., Villanueva, M.C., Vaz, S., Coppin, F., Koubbi, P. \& Carpentier, A. (2014). Morphological variability of the shape of striped red mullet Mullus surmuletus in relation to stock discrimination between the Bay of Biscay and the eastern English Channel. Journal of Fish Biology, 84(4), 10631073. DOI: $10.1111 / \mathrm{jfb} .12345$

Martin, G.B. \& Thorrold, S.R. (2005). Temperature and salinity effects on magnesium, manganese, and barium incorporation in otoliths of larval and early juvenile spot Leiostomus xanthurus. Marine Ecology Progress Series, 293, 223-232. DOI: 10.3354/meps293223

Martucci, O., Pietrelli, L. \& Consiglio, C. (1993). Fish otoliths as indicators of the cormorant Phalacrocorax carbo diet (Aves, Pelecaniformes). Italian Journal of Zoology, 60(4), 393-396. DOI: 10.1080/11250009309355845

Miller, J.A. (2011). Effects of water temperature and barium concentration on otolith composition along a salinity gradient: implications for migratory 
Preliminary study on otolith chemistry and otolith morphology of two demersal fish species, European hake Merluccius merluccius (Linnaeus, 1758) and striped red mullet (Mullus surmuletus, Linnaeus, 1758) in the Sea of Marmara

reconstructions. Journal of Experimental Marine Biology and Ecology, 405(1-2), 42-52. DOI: 10.1016/j.jembe.2011.05.017

Monteiro, L.R., Di Beneditto, A.P.M., Guillermo, L.H. \& Rivera, L.A. (2005). Allometric changes and shape differentiation of sagitta otoliths in sciaenid fishes. Fisheries Research, 74(1-3), 288-299. DOI: 10.1016/j.fishres.2005.03.002

Morales-Nin, B., Swan, S.C., Gordon, J.D., Palmer, M., Geffen, A.J., Shimmield, T. \& Sawyer, T. (2005). Age-related trends in otolith chemistry of Merluccius merluccius from the north-eastern Atlantic Ocean and the western Mediterranean Sea. Marine and Freshwater Research, 56(5), 599-607. DOI: 10.1071/MF04151

Morales-Nin, B., Pérez-Mayol, S., Palmer, M. \& Geffen, A.J. (2014). Coping with connectivity between populations of Merluccius merluccius: An elusive topic. Journal of Marine Systems, 138, 211-219. DOI: 10.1016/j.jmarsys.2014.04.009

Morat, F., Mante, A., Drunat, E., Dabat, J., Bonhomme, P., Harmelin-Vivien, M. \& Letourneur, Y. (2014). Diet of Mediterranean European shag, Phalacrocorax aristotelis desmarestii, in a northwestern Mediterranean area: a competitor for local fisheries. Scientific reports of Port-Cros National Park, 28, 113-132.

Özpiçak, M., Saygın, S. \& Polat, N. (2017). The length-weight and lengthlength relationships of bluefish, Pomatomus saltatrix (Linnaeus, 1766) from Samsun, middle Black Sea region. Natural and Engineering Sciences, 2(3), 28-36. DOI: 10.28978/nesciences.349265

Pannella, G. (1971). Fish otoliths: daily growth layers and periodical patterns. Science, 173(4002), 1124-1127. DOI: 10.1126/science.173.4002.1124

Ponton, D. (2006). Is geometric morphometrics efficient for comparing otolith shape of different fish species? Journal of Morphology, 267(6), 750-757. DOl: 10.1002/jmor.10439

Popper, A.N. \& Coombs, S. (1980). Auditory mechanisms in teleost fishes: significant variations in both hearing capabilities and auditory structures are found among species of bony fishes. American Scientist, 68(4), 429440.

Popper, A.N., Ramcharitar, J. \& Campana, S. E. (2005). Why otoliths? Insights from inner ear physiology and fisheries biology. Marine and freshwater Research, 56(5), 497-504. DOI: 10.1071/MF04267

Reis-Santos, P., Tanner, S.E., Elsdon, T. S., Cabral, H. N. \& Gillanders, B.M. (2013). Effects of temperature, salinity and water composition on otolith elemental incorporation of Dicentrarchus labrax. Journal of Experimental Marine Biology and Ecology, 446, 245-252. DOI: 10.1016/j.jembe.2013.05.027

Rieman, B.E., Myers, D.L. \& Nielsen, R.L. (1994). Use of otolith microchemistry to discriminate Oncorhynchus nerka of resident and anadromous origin. Canadian Journal of Fisheries and Aquatic Sciences, 51(1), 68-77. DOI: 10.1139/f94-009

Rooker, J.R., Secor, D.H., Zdanowicz, V.S. \& Itoh, T. (2001). Discrimination of northern bluefin tuna from nursery areas in the Pacific Ocean using otolith chemistry. Marine Ecology Progress Series, 218, 275-282. DOI: $10.3354 /$ meps 218275

Sarimin, A.S. \& Mohamed, C.A.R. (2014). Sr/Ca, $\mathrm{Mg} / \mathrm{Ca}$ and $\mathrm{Ba} / \mathrm{Ca}$ ratios in the otolith of sea bass in Peninsular Malaysia as salinity influence markers. Sains Malaysiana, 43(5), 757-766.

Secor, D.H., Trice, T.M. \& Hornick, H.T. (1995). Validation of otolith-based ageing and a comparison of otolith and scale-based ageing in markrecaptured Chesapeake Bay striped bass, Morone saxatilis. Fishery Bulletin, 93(1), 186-190.

Schwarzhans, W. (1999). A comparative morphological treatise of recent and fossil otoliths of the order Pleuronectiformes. In F.H. Pfeil (Ed.), Piscium Catalogus: Part Otolithi Piscium, 2: 1-391, Verlag F. Pfeil, München.

Sturrock, A.M., Trueman, C.N., Darnaude, A.M. \& Hunter, E. (2012). Can otolith elemental chemistry retrospectively track migrations in fully marine fishes? Journal of Fish Biology, 81(2), 766-795.

DOI: 10.1111/j.1095-8649.2012.03372.x

Sturrock, A.M., Hunter, E., Milton, J. A., E.I.M.F., Johnson, R.C., Waring, C.P. \& Trueman, C.N. (2015). Quantifying physiological influences on otolith microchemistry. Methods in Ecology and Evolution, 6(7), 806-816. DOI: 10.1111/2041-210X.12381

Swan, S.C., Geffen, A.J., Morales-Nin, B., Gordon, J.D., Shimmield, T., Sawyer, T. \& Massuti, E. (2006). Otolith chemistry: an aid to stock separation of Helicolenus dactylopterus (bluemouth) and Merluccius merluccius (European hake) in the Northeast Atlantic and Mediterranean. ICES Journal of Marine Science, 63(3), 504-513. DOI: 10.1016/j.icesjms.2005.08.012

Quinn, T.P. (1993). A review of homing and straying of wild and hatcheryproduced salmon. Fisheries research, 18(1-2), 29-44. DOI: 10.1016/0165-7836(93)90038-9

Thorrold, S.R., Campana, S.E., Jones, C.M. \& Swart, P.K. (1997). Factors determining $\delta 13 \mathrm{C}$ and $\delta 180$ fractionation in aragonitic otoliths of marine fish. Geochimica et Cosmochimica Acta, 61(14), 2909-2919. DOI: 10.1016/S0016-7037(97)00141-5

Thorrold, S.R., Latkoczy, C., Swart, P.K. \& Jones, C. M. (2001). Natal homing in a marine fish metapopulation. Science, 291(5502), 297-299. DOI: 10.1126/science.291.5502.297

Tracey, S. R., Lyle, J.M., \& Duhamel, G. (2006). Application of elliptical Fourier analysis of otolith form as a tool for stock identification. Fisheries Research, 77(2), 138-147. DOI: 10.1016/j.fishres.2005.10.013

Torres, G.J., Lombarte, A. \& Morales-Nin, B. (2000). Variability of the sulcus acusticus in the sagittal otolith of the genus Merluccius (Merlucciidae). Fisheries Research, 46(1-3), 5-13. DOI: 10.1016/S0165-7836(00)00128-4

Turan, C. (2006). The use of otolith shape and chemistry to determine stock structure of Mediterranean horse mackerel Trachurus mediterraneus (Steindachner). Journal of Fish Biology, 69, 165-180. DOI: 10.1111/j.1095-8649.2006.01266.x

TÜiK (2021). Türkiye İstatistik Kurumu. World Wide Web electronic publication. Retrieved in January 21, 2021 from https://data.tuik.gov.tr.

Tuset, V.M., Lozano, I.J., González, J.A., Pertusa, J.F., \& García-Díaz, M.M. (2003). Shape indices to identify regional differences in otolith morphology of comber, Serranus cabrilla (L., 1758). Journal of Applied Ichthyology, 19(2), 88-93. DOI: 10.1046/j.1439-0426.2003.00344.x

Tuset, V.M., Lombarte, A. \& Assis, C.A. (2008). Otolith atlas for the western Mediterranean, north and central eastern Atlantic. Scientia Marina, 72(S1), 7-198. DOI: 10.3989/scimar.2008.72s17

Velando, A. \& Freire, J. (1999). Intercolony and seasonal differences in the breeding diet of European shags on the Galician coast (NW Spain). Marine Ecology Progress Series, 188, 225-236.

DOI: 10.3354/meps 188225

Wells, B.K., Thorrold, S.R. \& Jones, C.M. (2000). Geographic variation in trace element composition of juvenile weakfish scales. Transactions of the American Fisheries Society, 129(4), 889-900.

DOI: 10.1577/1548-8659(2000)129<0889:GVITEC>2.3.CO;2

Yıldız, T. \& Karakulak, F.S. (2018). Batı Karadeniz (Şile-lğneada) dip trol balıkçılı̆ında av kompozisyonu. Journal of Aquaculture Engineering and Fisheries Research, 4(1), 20-34. 